\title{
For more than
}

\section{forty years...}

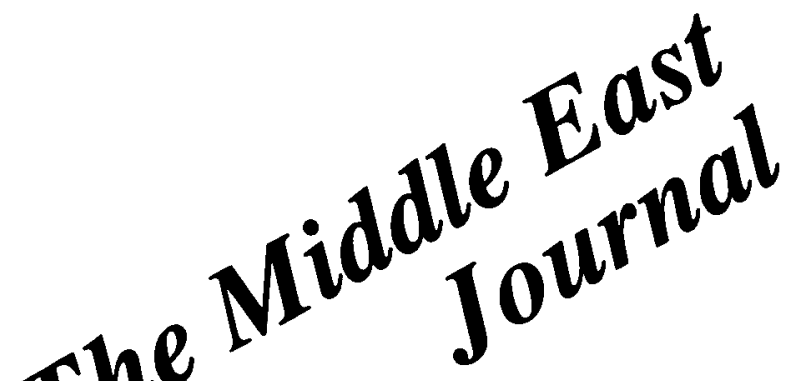

has been

providing insightful

articles and

up-to-date

information on

the contemporary

Middle East

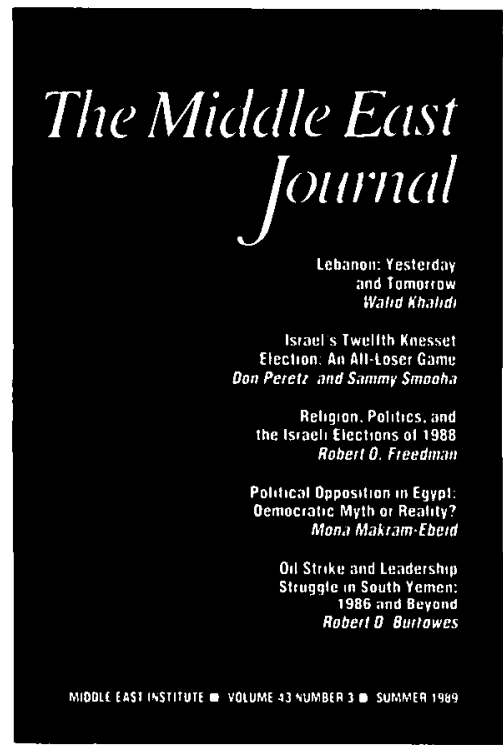

Indiana

University

Press

Quarterly. Subscriptions: $\$ 25$ individuals (one year), $\$ 47.50$ individuals (two years), $\$ 35$ institutions (outside US, add $\$ 9.50$ surface, $\$ 27.50$ airmail postage per year). Send orders to Indiana University Press, 10th \& Morton Streets, Bloomington, Indiana 47405. 


\section{Arabic at Middlebury}

\section{Summer 1990}

Middlebury College creates a total linguistic and cultural environment on its Vermont campus for the study of Modern Standard Arabic (contemporary al-Fushiā).

Students from beginning to advanced levels work and live with an international faculty and pledge to speak only Arabic for the entire session. In nine weeks, students complete the equivalent of a full academic year of study and acquire fluency in spoken Fușị.

June 8-August 10

Total Fees: $\$ 4,480$

(Tuition \$2,950; Board \$1,080; Room \$450)

For more information or an application contact:

The School of Arabic - MES

Middlebury College

Middlebury, VT 05753 - 6131

(802) 388-3711, ext. 5512

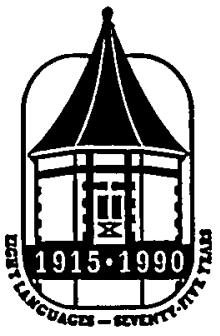




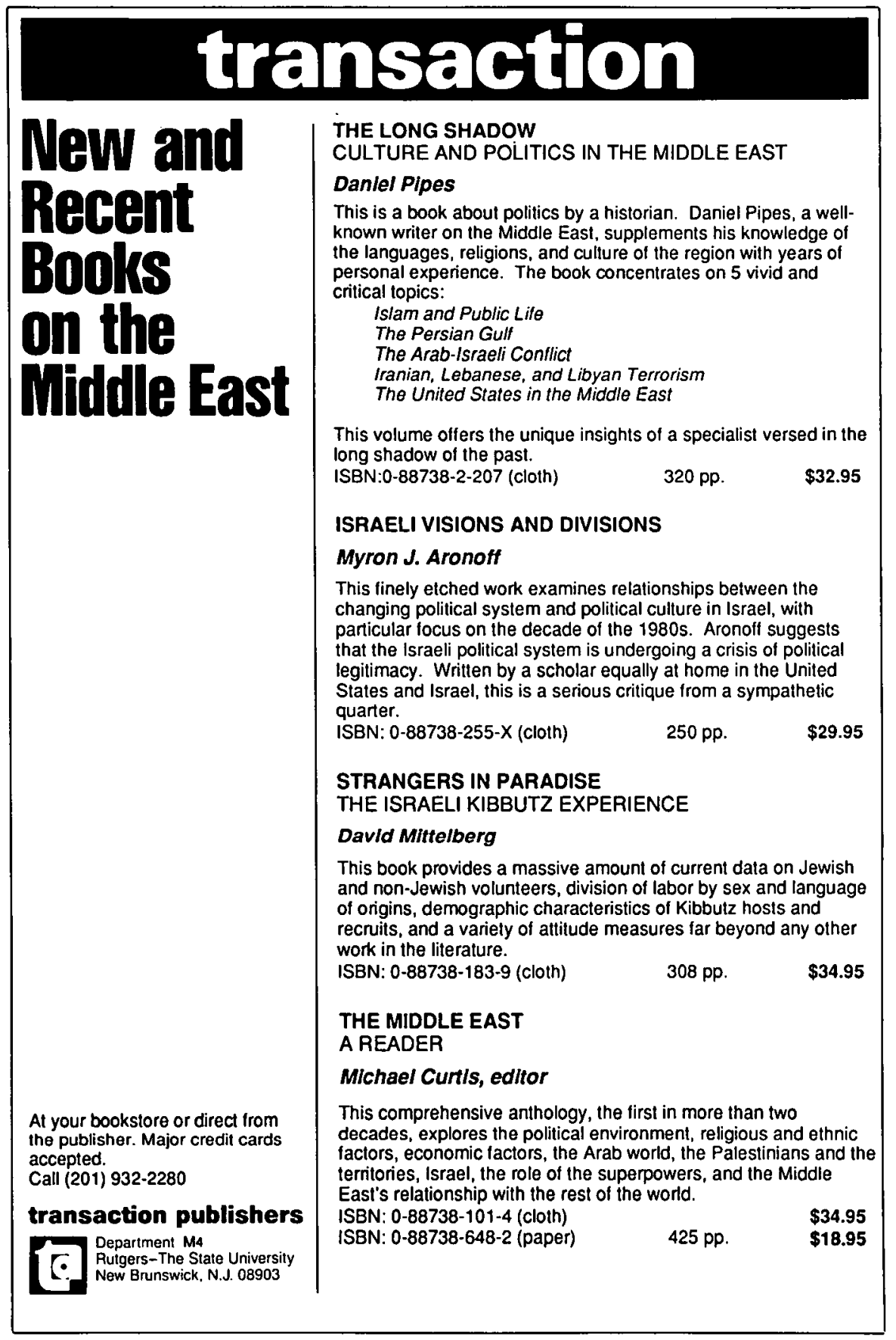




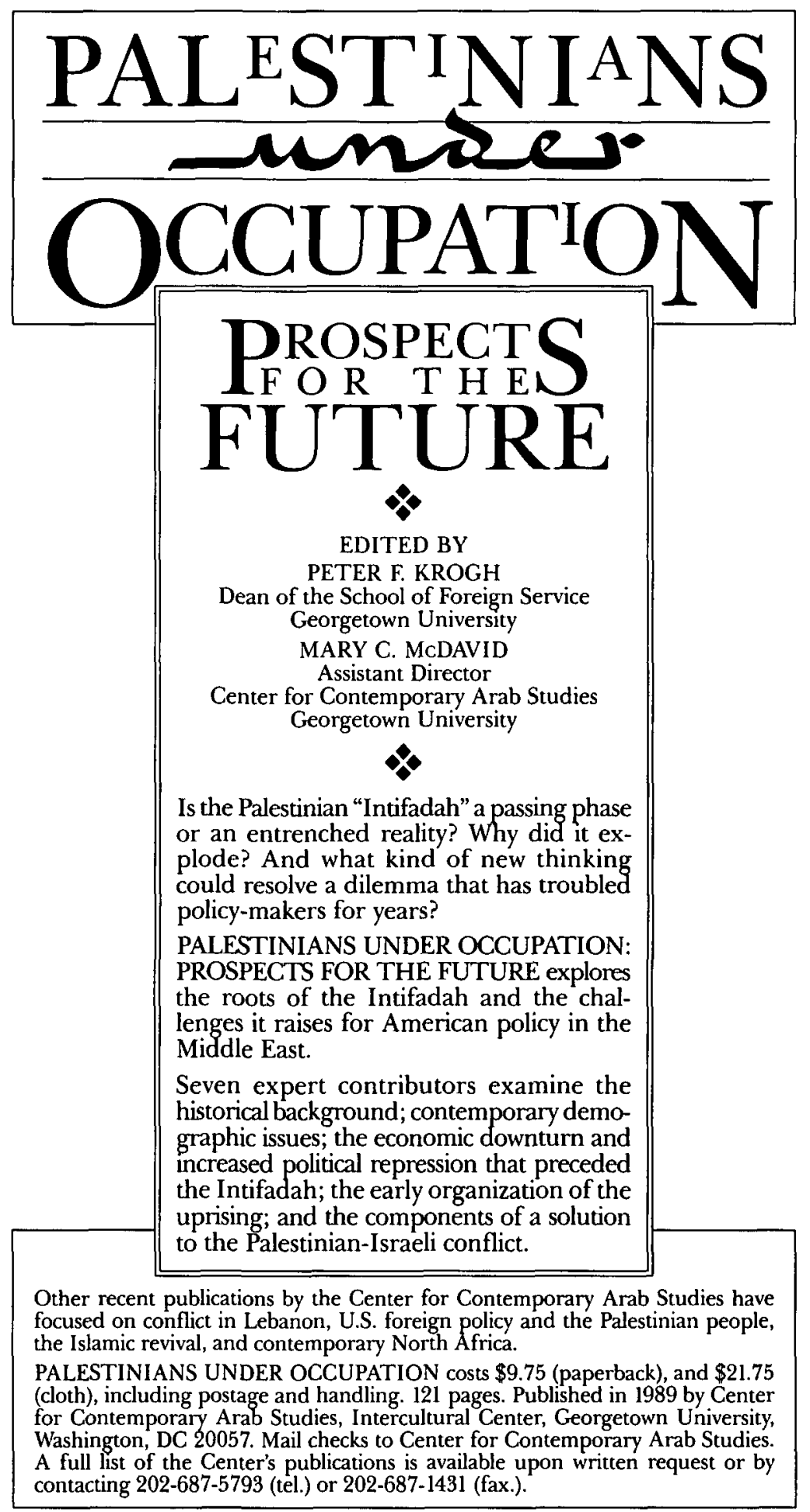




\section{MEDITERRANEAN HISTORICAL REVIEW}

The Mediterranean Historical Review provides an international forum for the discussion of topics of regional interest in the ancient, medieval and modern history of the Mediterranean basin, with an emphasis on questions whose relevance transcends a specific area or period. In addition to articles, the MHR includes annotated testimonia and book reviews.

\section{Editors: Shlomo Ben-Ami; Irad Malkin Aranne School of History, Tel Aviv University}

\section{Articles from recent and forthcoming issues include:}

Maurice Aymard

Paul Cartledge

Aryeh Kasher

William M. Murray Irad Malkin and Nino Shmueli

Zeev Rubin

Jean Richard

Barbara M. Kreutz

Jacques Le Goff

Armando Montanari

André Nouschi

Dodern Winds Equal Ancient Winds? Jewish Migration in the Mediterranean Countries in the Hellenistic-Roman Era The City of the Blind and the Founding of Byzantium emma of the Roman Empire in Late Antiquity Frankish Power in tbe Eastern Mediterranean The Ecology of Maritime Success: The Puzzling Case of Amalfi St. Louis and the Mediterranean

The Recent Development of Port Cities in Soutbern Europe Notes on French Expansion in the Mediterranean during the Nineteenth and Twentieth Centuries Stanley G. Payne The Concept of 'Soutbern Europe' and Political Development Yaacov Shavit 'Mediterraneanism': The Origins, Meaning, and Application of a Geo-Cultural

Testimonia

Tova Rosen

Michael Winter

The Hebrew Mariner and the Beast A Statute for the Mercantile Fleet in Eighteenth-Century Egypt

Contributions and editorial correspondence should be sent to the Editors, Mediterranean Historical Review, Aranne School of History, Tel Aviv University, Tel Aviv 69978, Israel.

Two issues per year (June/December)

Annual Subscription Rates: Institutions $\$ 60(£ 36)$

Individuals $\$ 35(\$ 20)$

US Subscription Enquiries

Journals: Allen Press Inc., Subscription Services, P.O.Box 368, Lawrence, Kansas 66044, USA. Tel: (913)843-1235; Telefax: (913)843-1274

Books: $\quad$ Frank Cass, c/o 8705 Bollman Place, Savage, MD 20763, USA Tel: (301)306-0400; Telefax: (301) 459-2118

Gainsborough House, 11 Gainsborough Road, London E11 1RS, England Tel: 01-5304226 Telex: 897719 


\section{The Jerusalem Journal of International Relations}

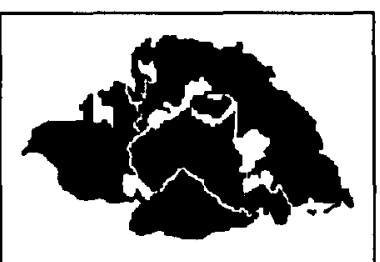

In a time of continuous tensions between superpowers as well as smaller countries; of escalation in conventional, chemical and nuclear weapons; of terrorists, attacks and political hijackings, the study of international

relations is of vital importance. And for those who have a vital interest in the field-who teach, study, manage, govern or make strategic decisions large or small-The Jerusalem Journal of International Relations is essential reading. Published in March, June, September, and December.

To subscribe return the order form below or charge your subscription by calling our toll-free number : 1-800-537-JHUP.

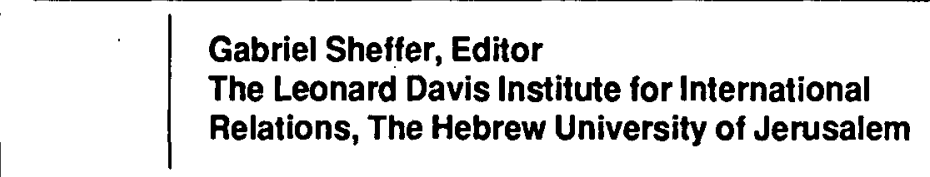

Please enter my one-year subscription to Jerusalem Journal of International Relations!

Subscription:

$\square$ Individual $\$ 26.00$

Institutions $\$ 40.00$

Payment:

$\square$ Check or money order

Acct. \#

MasterCard $\square$ VISA

Signature

Exp. Date

Name

Address

City/State/Zip

Send orders to: The Johns Hopkins University Press, Journals Division, 701 W. 40th Street, Suite 275, Baltimore, MD 21211. Prepayment is required before shipment. Subscribers in Mexico and Canada add $\$ 6.40$ postage; subscribers outside North America add $\$ 7.00$ air freight. Payment must be drawnona U.S. bank or be by international money order, payable to The Johns Hopkins University Press. Maryland residents add $5 \%$ sales tax. 


\section{Cambridge University Press}

Now in paperback...

\section{A History of Islamic Societies \\ Ira M. Lapidus}

"This book is a major undertaking and deserves to be saluted as an outstanding achievement. Professor Lapidus' A History of Islamic Societies belongs to a rare breed of works which appear only once every two decades." - Third World Quarterly

A History of Islamic Societies provides an authoritative and comprehensive treatment of the civilizations and patterns of life of Muslims throughout the world.

Paper $\$ 19.95$

\section{The Modern Economic and Social History of the Middle East in Its World Context \\ Editor, Georges Sabagh}

The political upheavals and momentous social and economic disturbances which the Middle East has witnessed during the past few decades will undoubtedly have a lasting impact on its people and the Muslim world in general. In this book the nature and effects of these changes are examined in essays that offer a wealth of insight, theoretical argument and information about salient aspects of Middle Eastern social and economic history.

Contributors: Charles Issawi, Roger Owen, Homa Katouzian, Bent Hansen, Samir Khalaf, Afaf Lutfi Al-Sayyid Marsot and Carter Vaughn Findley.

Hardeover $\$ 39.50$

\section{The Anthropology of Justice}

\section{Law as Culture in Islamic Society}

Lawrence Rosen

In this first full-scale study of the operations of a modern Islamic court of law in the Arabicspeaking world, the author examines the cultural foundations of judicial discretion. He shows how the analysis of legal systems requires an understanding of the concepts and relationships encountered in everyday life. By drawing comparisons with Anglo-American law, the author demonstrates that in both societies, it is necessary to view law as integral to culture and culture as indispensable to law.

Lewis Henry Morgan Lectures

Handcover $\$ 34.50$ Paper $\$ 12.95$

\section{Cairo University and the Making of Modern Egypt \\ Donald Malcolm Reid}

Cairo University has been crucially important in shaping the national life of twentieth-century Egypt. Professor Reid has drawn on university archives hitherto untapped by Western scholars and on a wide range of other Arabic and Western sources. Nasser and Sadat, Kings Fuad and Faruq, reformers Zaghlul and Nobel Prize winner Najib Mahfuz, all feature prominently in this fascinating history of Egypt's most important educational institution.

Cambridge Middle East Library 23

Handcover about $\$ 49.50$

\section{State and Society in Mid-Nineteenth-Century Egypt}

\section{Ehud R. Toledano}

Written in a way that will permanently affect our view of Egyptian history, this book argues that mid-nineteenth-century Egypt was still an Ottoman province, with a provincial Ottoman elite that was only gradually becoming Egyptian. Dr. Toledano's valuable knowledge of Ottoman, Arabic and European documents and his use of a wide variety of sources, including police and court records, chronicles and travel literature, make this an important contribution to what is a neglected period of Egyptian history.

Hardcover about $\$ 54.50$

\section{Cambridge University Preşs}

40 West 20th Street, NY, NY 10011. Call toll-free: 800-872-7423, outside NY State. 800-227-0247. NY State only. MasterCard \& VISA accepted. Prices subject to change. 


\section{ENGLISH TRANSLITERATION SYSTEM CONSONANTS}

Column Headings: $\mathrm{A}=$ Arabic, $\mathrm{P}=$ Persian, $\mathrm{OT}=$ Ottoman Turkish, $\mathrm{M} \mathrm{IT}=$ Modern Turkish

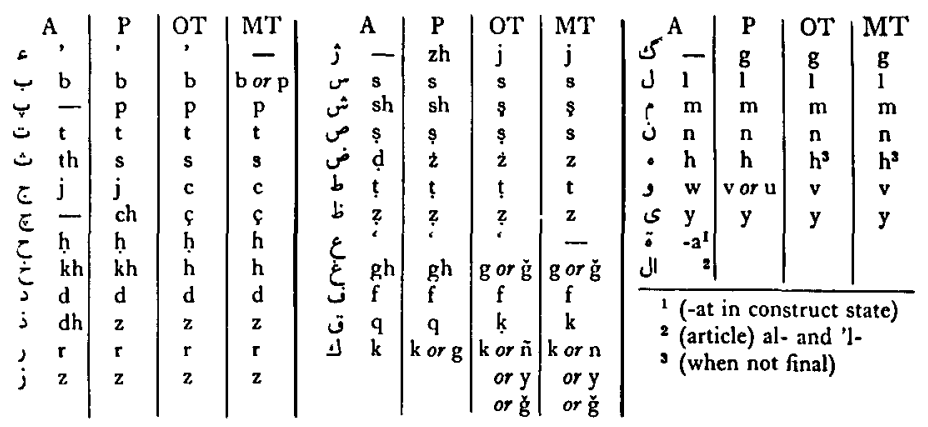

\section{VOWELS}

\section{ARABIC AND PERSIAN OTTOMAN TURKISH MODERN TURKISH}

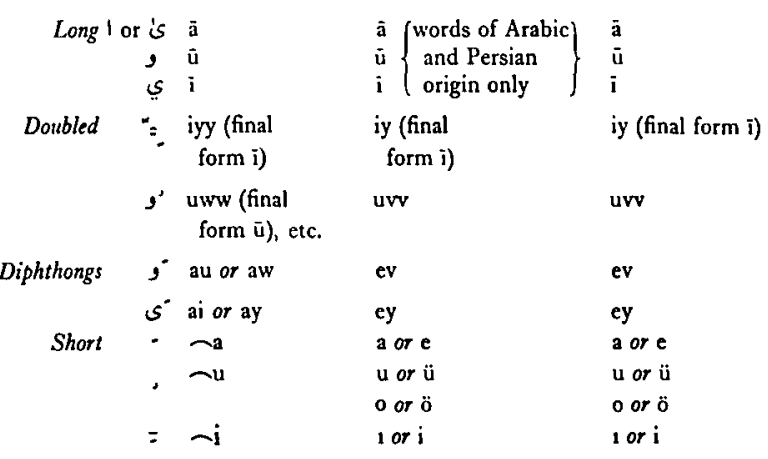

For Ottoman Turkish, authors may either transliterate or use the modern Turkish orthography. 


\section{Contributions and Editorial Correspondence}

Send article submissions to the Editorial Office (address on inside front cover). Books for review should also be sent to the Editor for forwarding to the Book Review Editors. Unsolicited book reviews cannot be accepted for publication.

\section{Manuscript Preparation and Style}

General. An article must be in English, should not exceed 40 typewritten pages, and should be typed on $81 / 2^{\prime \prime} \times 11^{\prime \prime}$ or A4 white bond paper with ample margins on all sides. The entire manuscript-including notes, tables, and references-must be typed double-spaced and numbered consecutively. Title and author's name should be centered at the top of the first text page. Institutional affiliation and location should appear at the bottom of the last text page. The Editor may find it necessary to return manuscripts for reworking or retyping that do not conform to these requirements.

Text. Use a 5-character paragraph indent. Avoid hyphenating words at the end of lines. Do not use desk-top publishing features (e.g., right margin justification or bold and italic typefaces). Block indent long quotations (more than 50 words). Never cross-reference.

Endnotes and References. Notes must be numbered consecutively throughout the text, typed double-spaced in paragraph style, and grouped together as a unit following the text. Footnotes at the bottom of the text page are not permitted. Any acknowledgment of grant support, substantial assistance, etc., should be typed as an Author's Note above the first note. Provide the full name of the author as it appears on the publication. All titles in nonRoman alphabets (Arabic, Cyrillic, etc.) must be transliterated. Foreign titles in Roman alphabets should be capitalized as they would be in that particular language. An English translation of nonstandard language titles should be provided in parentheses after the title. The style of note citations should conform with the following examples:

'Marshall G. S. Hodgson, The Venture of Islam, 3 vols. (Chicago, 1974), vol. III, The Gunpowder Empires and Modern Times, p. 5.

${ }^{2}$ Majid Fakhry, A History of Islamic Philosophy, 2nd ed. (New York, 1983), pp. 55-56, 61 n.75.

${ }^{3}$ Howard Crane, trans. and ed., Rîsãle-î Mímäríyye: An Early-Seventeenth-Century Ottoman Treatise on Architecture (Studies in Islamic Art and Architecture 1) (Leiden, 1987), p. 71.

"Bruce M. Russett, "Delineating International Regions," in J. David Singer, ed., Quantitative International Politics (New York, 1968), pp. 45-68.

${ }^{5}$ Clifford Geertz, "Toutes Directions: Reading the Signs in an Urban Sprawl," International Journal of Middle East Studies, 21 (August, 1989), 291-306.

When references to the same work follow without interruption use ibid. When notes to the same work follow after interruption, use the author's last name and a shortened title of the book or article. Do not use op. cit.:

${ }^{6}$ Hodgson, Venture of Islam, vol. III, p. 5.

${ }^{7}$ Ibid., pp. 7-9.

As a less-preferred alternative, authors may use the social science method of citation. In the text, cite author and year in parentheses. In the reference section, provide the full citation: author's full name, title, city of publication, publisher, and year. IJMES does not publish bibliographies.

Foreign Words and Transliteration. All Arabic words found in an unabridged dictionary (e.g. ulema, sheikh, qadi, Sunni, mihrab, minbar, madrasa, masjid, jami ${ }^{\varsigma}$, hadith, suq) should be treated as English words, that is, not underlined and without diacriticals. Contemporary names and places should be spelled as they are found in such standard publications as the New York Times. All other transliterated words and phrases should be underlined and all their diacriticals included throughout the text. Be sure to distinguish between the hamza, ' ayn, and the apostrophe in the text. No diacritical marks other than the hamza and the 'ayn should appear in any proper names (e.g., names of people, dynasties, places) and names of well-known literary works (Qur'an, Shahnama), except: works written in Arabic, Persian, and Ottoman Turkish and cited in transliteration in the notes must include diacriticals for both author and title.

Transliteration System. All non-Roman alphabets must be transliterated, and authors are responsible for the consistency and accuracy of their transliterations. For Arabic and Persian, IJMES uses the modified Encyclopaedia of Islam system: $q a f=\mathrm{q}$ not $\mathrm{k}$; $j \mathrm{im}=\mathrm{j}$ not $\mathrm{dj}$; roman double-letter equivalents are not underlined; the $l$ of $a l$ is not assimilated to the following consonant; $t a$ marbuta is rendered $a$ not $a h$; the adjectival $-y a$ followed by ta marbuta is rendered-iyya. Except at the beginning of an English sentence or endnote, only proper names are capitalized. For Ottoman Turkish, use either the Encyclopaedia of Islam system or modern Turkish orthography. For treatment of common Turkish words, such as medrese, turbe, etc., follow the rules on anglicizing Arabic and Persian words.

Dates. IJMES does not use double dating. Use common era (A.D.) dates only, unless quoting from an original source, in which case use the date as quoted (hijra, solar, etc.) with the common-era equivalent in parenthesis.

Tables and Figures. Tables and figures must be cited in the text, e.g., (see Table 1). They should be numbered consecutively in arabic numbers, captioned, and appear as a unit following the notes section. They cannot be interspersed in the text. Diagrams must be professionally rendered or computer generated; details should be large enough to remain legible at $50 \%$ reduction. Belowstandard artwork will be returned to the author for replacement. All artwork must be numbered and labeled with the author's name and article title. For halftones or other illustrations, consult the Editor.

\section{Publishing Information}

Production. The publisher reserves the right to copyedit manuscripts to conform to the journal's style, which follows the rules found in the Chicago Manual of Style. Spelling will be edited to conform to American usage. More substantial editing will be returned to the author for approval before publication.

The lead author will receive one set of proofs for the correction of typographical or factual errors only. No rewriting will be allowed in the proof stage. Authors must return the material to the editorial office within $\mathbf{4 8}$ hours of receipt or approval will be assumed.

Offprints. The lead author of an article (but not bookreview) will receive 50 free offprints of the article. Additional offprints may be purchased if ordered at the proof stage. Orders received after the issue is printed are subject to a $50 \%$ reprint surcharge.

Copyright and Originality. Submission of an article implies that it has not been simultaneously submitted or previously published elsewhere. Authors are responsible for obtaining permission to publish any material under copyright. Contributors will be asked to assign their own copyright, on certain conditions, to Cambridge University Press. 


\section{CONTENTS}

Editorial

Articles

Bruce Masters The 1850 Events in Aleppo: An Aftershock of Syria's Incorporation into the Capitalist World System

Susan E. Waltz Another View of Feminine Networks: Tunisian Women and the Development of Political Efficacy

Sterphen Frederic Dale Steppe Humanism: The Autobiographical Writings of Zahit al-Din Muhammad Babur, 1483-1530

Ralph R. Sell International Affinities in Modern Egypt: Results from a Social Distance Survey of Elite Students

Alıson M. Bowes The Experiment That Did Not Fail: Image and Reality in the Israeli Kibbutz

\section{Book Reviews}

Avı Shr.aim. Collusion Across the Jordan: King Abdullah, the Zionist Movement. and the Partition of Palestine (Gabriel Sheffer)

Shlomo D. Goltein, A Mediterranean Society: The Jewish Communities of the Arah World as Portrayed in the Documents of the Cairo Geniza, Vol. V: The Indivichual: Portrait of a Medieval Personality of the High Middle Ages as Reflerted in the Cairo Geniza (Mark R. Cohen)

107108

Said Amir Arjomand, ed., Authority and Political Culture in Shi' ism (Shahrough Akhavi)

108110

Thieray Bianquis, Damas et la Syrie sous la domination fatimide (359-468/969-1076). Essai d'interpretation de chroniques arabes médiévales (Michael G. Morony)

Fedwa Malti-Douglas, Blindness and Autobiography: Al-Ayyām of Tähä Husayn (Michael Beard)

Samir A. Mutawi, Jordon in the 1967 War (Laurie A. Brand)

Barbara Freyer Stowasser, ed., The lslamic Impulse (Patrick D. Gafiney)

Shahram Chubin and Charles Tripp, Iram and Iraq at War (AbduJ-Reda Assiri)

118120

Masid KHAdduri. The Gulf War: The Origin and Implications of the Iraq-Iran Conflict (Abdul-Reda Assiri)

Katherine P. Ewing. ed., Sharitat and Ambiguity in South Asion Islam (Gregory C. Kozlowski)

GADI Wolfsfeld, The Politics of Provocation: Participation and Protest in Lsrael (Russell A. Stone)

Halm Gerser, Economy and Society in an Ottoman Cîty: Bursa. 1600-1700 (Fatma Müge Göçek)

Notes and Comments

Cornell. H. Fleiscrer, Response to Rhoads Murphey's Review Article of Bureaucrat and Intellectual in the Ottoman Empire: The Historian.Mustafa Ali, 1546-1600

\section{CAMBRIDGE UNIVERSITY PRESS}

The Edinburgh Building, Shaftesbury Road, Cambridge CB2 2RU, England 40 West 20th Street, New York, N.Y. 10011, U.S.A.

10 Stamford Raad, Oakleigh, Melbourne 3166. Australia

Printed in the United States of America 